\title{
'Dentists' and the establishment of the Anglo-American profession in the eighteenth century: part 2. Public recognition
}

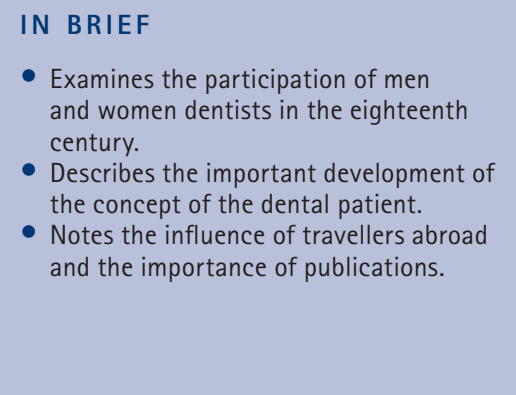

\author{
M. Bishop ${ }^{1}$
}

This series of papers examines how the Anglo-American dental profession was established in the eighteenth century, examining its need for a name and identity, public recognition and official status. This second paper will explore the introduction of the title dentist to the public, and the development of the concept of the dental patient

\section{INTRODUCTION}

In 2005, Stephen Hancocks, in an editorial discussing appropriate names to apply to members of the dental team said: 'They may be just words but they are essential words for, and words essential to, our identity. Until we can agree that identity among ourselves we cannot expect others such as patients, public, media and politicians to either understand our relationship to one another or indeed to respect our collective voice when we choose to, or need to, use it.' ${ }^{\prime}$

Hancocks' statement can be broken down into three components: self-awareness (agreed identity among ourselves), public awareness (others such as patients, public, media) and political identity (politicians [who] understand our relationship to one another [and] respect our collective voice).

The previous paper in this series ${ }^{2}$ looked at the way in which the adoption of the name dentist satisfied the first of Hancocks' criteria, self-awareness and the establishment of an agreed identity. This paper looks at the next essential, public awareness, as it was cultivated by the profession in the second half of the eighteenth century.

\section{PUBLICATIONS BY DENTISTS AND REFERRING TO DENTISTS}

The extent of public awareness of the new title that could be assumed by 1791 is clearly revealed in the tract, mentioned earlier in Part 1, by the surgeon Francis Spilsbury

\footnotetext{
'Unit for the History of Dentistry at King's College London Dental Institute
}

Correspondence to: Malcolm Bishop

Email:malcolmbishop57@btinternet.com

\section{Refereed Paper}

Accepted 18 June 2014

DOI: 10.1038/sj.bdj.2014.1003

${ }^{\circledR}$ British Dental Journal 2014; 217: 593-596
Every lady and gentleman their own dentist, as far as the operations will allow. ${ }^{3}$ This shows very clearly that by then the public at large could be trusted to know exactly what a dentist was and could do, and to distinguish that from the dental functions the laity might undertake themselves.

To a significant extent, this awareness was the product of publications designed either for internal consumption by the new profession, such as John Hunter's (1727-1793) seminal work on the teeth and dentistry of 1778 , in which he refers to dentists by that title alone, ${ }^{4}$ or those aimed at the public at large, in which the authors were entitling themselves dentist or surgeon dentist. Thomas Berdmore in 1768, just 23 years after the separation of the barbers and surgeons, was titled Surgeon-Dentist to His Majesty in his Treatise on the teeth etc (price $3 /-$ ). ${ }^{5}$ The Treatise was reviewed at length (five pages) in the Monthly Review in August, ${ }^{6}$ bringing the title before the public: Upon the whole, this is a plain, sensible, useful treatise; and calculated for the perusal of others, as well as those of the profession.'

Bartholomew Ruspini would have been less than pleased with the comparison made between his own treatise (price 2/-, also published in 1768), and Berdmore's: 'We shall not enter into any more particular account of this piece, as it is not calculated for the perusal of the generality of readers, and as it is in every respect inferior to the treatise on the same subject published by $\mathrm{Mr}$ Berdmore, and of which we have already given an account in this month's Review. ${ }^{6}$

These reviews went a long way to establishing the dentist as a significant member of the health-care community, and more than that. The findings by Spence in 1790, carefully reviewed in The Gentleman's Magazine and Historical Chronicle, that iatrogenic disease of the most serious kind could be laid at the door of those transplanting teeth 'In consequence of two living parts being brought into contact' reveals an early example of epidemiology and of serious public discussion well before a bacterial agent could be known.?

Thanks to the long and detailed review of Berdmore's Treatise we know that his careful in vitro experiments on toothpowders were made known to a much wider audience than just the purchasers of the treatise itself. 'Our Author ... proves by experiments the bad effects of some of the tinctures which are advertised for cleaning the teeth: and he concludes the chapter with directions for preserving the teeth from infancy to old age; 'and by such care and treatment, he says, as shall be free from all the dangers which belong to powders, electuaries, and tinctures.'

The equally careful experiments made by Wooffendale in $1783^{8}$ (he improved on Berdmore's methodology by introducing controls) may not have been reviewed so generously, but it was under the title Surgeon-Dentist (Berdmore) or Dentist (Wooffendale) that such important scientific findings, so significant to dental public health, were brought to the attention of any 'patients' (his and Berdmore's word) who read his work, as well as fellow professionals (Wooffendale's work was advertised in the Medical Register of 1783.)

When Nicolas Dubois de Chemant (17531825 ?) came to London in 1791, the introduction of his mineral paste false teeth was promoted on the very clear health benefit of avoiding the use of human teeth and animal bone, adding further to the image 
of scientific dentistry and dentists. His Dissertation, which was to run to at least five English editions, disseminated his opinions and capabilities when published in $1797 . .^{9}$ In the frontispiece he retains his French title of Chirurgeon subtitling it Dentiste Inventeur ... one of the very few occasions where the original French 'Dentiste' is to be found in England.

\section{THE EIGHTEENTH CENTURY CULTIVATION OF 'THE DENTAL PATIENT'}

In the amusing introduction to his 'Treatise' of 1768, Berdmore said that the work was 'originally designed for artists [practitioners] who are not much given to reading [original italics], and for patients who do not love too much trouble.' He may here have been earliest to address dental patients as patients, he was certainly the most important of the eighteenth century writers on dentistry to do so.

His pupil (self-proclaimed) Wooffendale continued with this usage (as old as Chaucer in medicine) calling those he treated 'patients' in his own book published in $1783,{ }^{10}$ and Hancocks' statement about the importance of names is illustrated by the identification of those they treated as patients, a specific group, not individuals.

The title is notably absent from the writings of De Chemant and Ruspini, who, in giving their case reports refer to individual Ladies or Gentlemen, even in the case of Ruspini naming them, and the difference in emphasis is noticeable - Berdmore and Wooffendale emphasising continuity of care, the others treatment on demand.

The invention or conception of the dental patient was radical, for the dental patient differed then as now from the medical patient in that he or she was and is normally healthy, and was encouraged to visit the dentist regularly for prevention and the maintenance of oral health as much as, or more than, for the mere treatment of disease.

The concept started young, and first brought children to be helped through the dangerous period of teething (as it was then perceived) and later to remedy malocclusion. For the older child, Hargreaves gives Laudimiey the credit for being the first dentist to visit educational establishments regularly, from about $1760,{ }^{11}$ and as she notes, and the official appointments of Rae and Wooffendale and others confirm, this important function of dentists had become common by the end of the century.

It is a short conceptual step from the dentist visiting children regularly, to adults as patients continuing to visit the dentist regularly, when the adult patient came for inspection and the grooming/preventive function of scaling, and was a consumer of toothpastes, powders, and mouthwashes, all provided by the dentists. Mrs de St Raymond's dentifrice cost five shillings a box ( $£ 14.00$ in 2005$)$.

A further landmark validating the patient as a collaborator in dental health care ('Every lady and gentleman their own dentist'3) came in the 1780s with the semi-mass production of the toothbrush by William Addis (17341808), and the brush becoming a fashionable item to possess. In 1789, in America, Isaac Greenwood said when illustrating an advertisement with crossed brushes: "Attend to your teeth, and preserve your health and beauty and them from decay'. ${ }^{12}$ Pottery makers such as Spode made special containers for these expensive items (Fig. 1). A charming proof of the success of eighteenth century preventive dental education for the young is given in a letter from Lady Nelson written in 1794 'My child [Nelson's step-son] I figure in myself good, obedient to you ... Do make him clean his teeth not cross ways but upwards and downwards.' ${ }^{13}$

The growing wealth of England that enabled the new patients to be able to pay for their treatment had less desirable but linked consequences, as the need for restorations, extractions, and prosthetics became regrettably more and more essential as prosperity and the sugar industry went hand in hand with a huge increase in caries. Also the population in London exploded in the eighteenth century and with it the core of the population who could be influenced to become patients.

\section{THE ENGLISH \\ GENTLEMAN ABROAD}

That the idea of regular visits to a dentist was already current at the upper end of society is confirmed in correspondence between Lord Chesterfield (1694-1773) and his son Philip Stanhope (1732-1768). Lord Chesterfield was very concerned that his son should not neglect his teeth as he himself had done, and refers to tooth care several times in his letters. When the young man was in Turin in 1749 he was advised to consult 'The best operator for the teeth', the old term. ${ }^{14}$ In Paris in 1750, however, he was advised to consult a named man (Claude) Mouton (-1762). ${ }^{15}$ Mouton had published his Essay d'Odontotechnie in $1746^{16}$ entitling himself Chirurgien Dentiste, and according to King ${ }^{17}$ being the fourth to use the title in a book after Fauchard.

The eighteenth century English traveller would have encountered the title Dentiste or Chirurgien Dentiste when in France, even if Chesterfield himself did not hear the word Dentiste, and his wayward son may

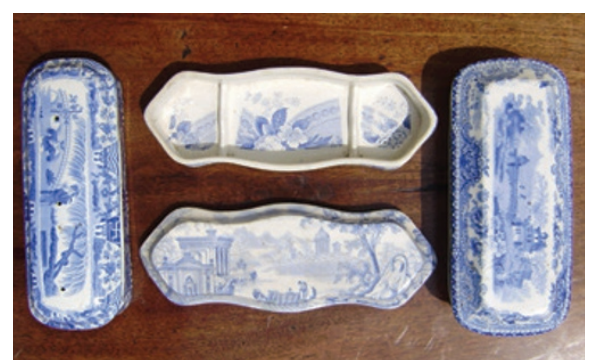

Fig. 1 Eighteenth century pottery toothbrush boxes. Private collection

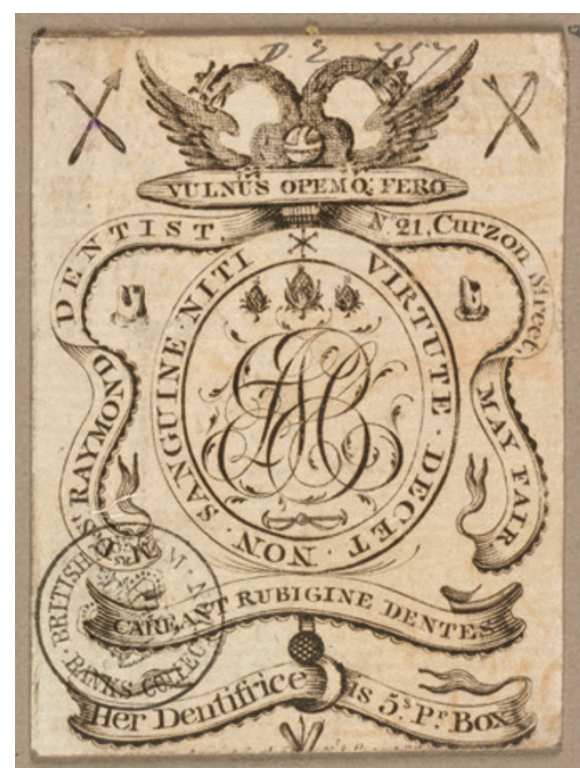

Fig. 2 Mrs de St Raymond. Trade card. ${ }^{\odot T h e}$ Trustees of the British Museum D,2.757

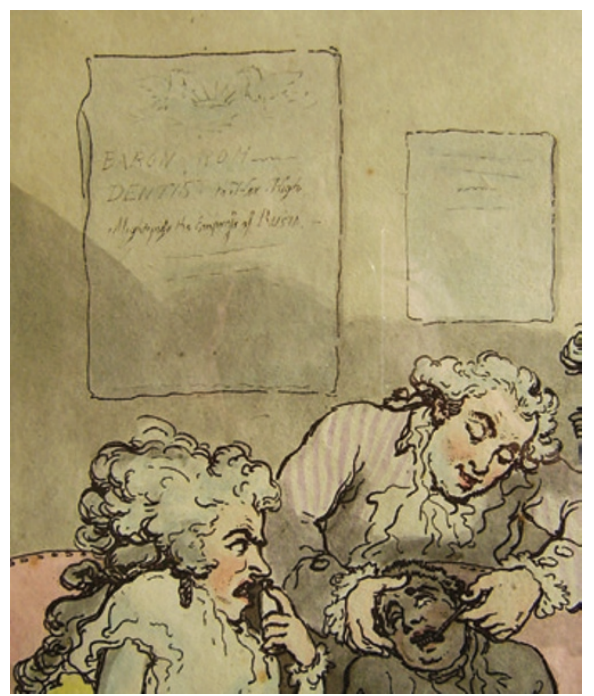

Fig. 3 'Baron ROM..... DENTIST to her High Majesty the Empress of RUSIA' (sic.) Rowlandson 1787. Detail. Private collection

not indeed have followed his father's advice and seen Mouton. By 1760, 23 years before the Medical Register performed the same function in England, the collective description was certainly established in the French Capital. Jeze's État ou Tableau de la Ville de Paris of that year listed 31 Dentistes: two who were 'Maistres en Chirurgerie', and 
27 'Experts' who were messieurs, and two 'Experts' who were mademoiselles. Any traveller to Paris at the time could have encountered the term. ${ }^{18}$

\section{WOMEN DENTISTS}

In England also there were women dentists, and the trade card for Mrs de St Raymond who practised in Mayfair is a model of its kind (Fig. 2). As well as being generalists using the new title some women dentists offered selective dentistry to women as patients, Mrs Levis and Mrs Griffiths saying that they were 'Ladies Dentists' [sic].

The pioneer was the 'Dentress' Mme Rauxcourt of Soho, who may indeed have the honour of being the earliest person in England to be a dentist (dentress being admitted as the feminine of dentist) and who advertised in 1751: Madam Rauxcourt, a famous Dentress, lately arrived from Paris, who served her time to the most famous Caperon $^{19}$ [Jean-François, dates uncertain, with whom Bartholomew Ruspini also claimed to have trained] Dentist to the King of France...

Women were practising before 1750; a 1719 example of an operator was the widow of the late Dr Povey, operator for the teeth. Her advertisement stated that she "Now follows in the same business at the Sign of the Queen's Arms and Dial next door to the tin shop near Exeter Exchange in the Strand: ${ }^{20}$ Later, in 1745 , and it must be assumed for some years earlier to have achieved her reputation, a female tooth-drawer is mentioned during Henry Fielding's last voyage: At Wapping, a female of great eminence in the art. ${ }^{21}$

Between 1766 and 1792, trade cards in the British Museum Banks Collection, Menzies Campbell $^{22}$ and Purland ${ }^{23}$ collections, demonstrate the existence of seven women practising as dentists on their own, or with relatives, including perhaps the earliest woman to manage a dentist's practice. In 1766 Jullion's widow entered into a public row in the press with Samuel Bellejean, Surgeon Dentist, who claimed to be Paul Jullion's successor. She made clear that he was not, and that she was continuing the business with an un-named assistant to do the technical work.

From 1775 Hannah Crippen continued her deceased husband's business as dentist and phlebotomist with an assistant, continuing until at least 1790. Over the same period Mrs de St. Raymond advertised as a dentist $^{24}$ (and see Fig. 2).In 1778 Mrs Levis advertised in the Bath Chronicle that she was a Ladies Dentist [sic]. Her husband advertised as a surgeon-dentist. ${ }^{25}$ Mrs Griffiths, another Ladies Dentist Etc. (sic. heading to her advertisement), advertised in the London
Morning Chronicle in 1780. (Her husband, a surgeon, was a prisoner of war in Spain. ${ }^{26}$ ) A further dentist in London was Mrs Hunter, advertising in 1791 and in 1792; Mr and Mrs Sedmond advertised their services as dentists in the Reading Mercury. ${ }^{27}$

The all-male Victorian profession was a short-term phenomenon.

\section{PRINTS AND CARICATURES}

Caricatures and prints were another way in which the new name was brought before the public. They were not only seen by their purchasers, but were exhibited in the shop windows of the publishers, providing colourful street entertainment. ${ }^{28}$ One 1760 s caricature $^{29}$ in the Purland Collection at the Wellcome Institute is both finely observed in its characters, and of particular interest in the context of the introduction of the title dentist, showing several transitional features. Although the caricature is labelled The Town Tooth Drawer, the doggerel verse beneath records the Cockney cheek of Poll the pot-girl from the 'Magpie' who addresses the operator familiarly (her hand is on his shoulder) as 'Doctor of Horses' (a nostalgic reminder of the less than reverential attitude of one or two of my own beloved DSAs) 'just as Dentist fast hold of his patient had got' and the smilingly indignant reply, sotto voce '...I vow says the Dentist, I ne'er met with his fellow' continuing to say that he is not like the Country Blacksmith, but 'extracts in an instant' ${ }^{30}$

Several caricatures were made of the famously eccentric dentist Martin van Butchell who painted his horse with spots (he called himself a dentist at least by $1770^{31}$ ), and a print by Rowlandson dated 1787, generally accepted to be of the Chevalier Ruspini, and entitled Transplanting of Teeth, features a poster on the wall referring to the 'Baron Rom..., Dentist to her High Majesty the Empress of Russia' (Fig. 3).

Other examples from the 1780s include The Dentist Scaling the Ladies Teeth of 1782, and The London Dentist of c. $1784 .^{32}$

\section{TRADE CARDS}

Trade cards and other ephemera from the later eighteenth century such as toothpowder boxes show the use of dentist, in preference to any other title, when presenting practitioners to the public. An example of a toothpowder box is one of James Parkinson's held in the Museum at the British Dental Association on which is printed: 'Successor to Berdmore, Dentist to the King. ${ }^{33}$ Trade cards also provided a medium for emphasising royal connections, and therefore the respectability of such dentists. Three good examples of these 'royal' trade cards in the
Banks Collection ${ }^{34}$ at the British Museum are the very similar ones issued by Hemet (Jacob Hemet 1729-90) and Scarman (Thomas Scarman 1744-1816), ${ }^{35}$ Dentists to her Majesty and their Royal Highnesses the Prince of Wales and Princess Amelia then by Scarman (on his own in 1792 after the death of Hemet), and by Law, whose card can be dated as later than 1786, when William Rae (1749-1786) died.

Dated between 1784 and the end of the century, the British Museum collection also includes trade cards for Spence, Talma, Whitewood (the American dentist who trained Waite senior), Bowes, Florance, and Lambe, as either dentists or surgeon dentists.

Mrs de St Raymond used her trade card (Fig. 2) to demonstrate her familiarity with a good education, adorning it with Latin tags; Joseph Addison's (1672-1719) motto: The weapon that wounds heals, Claudian (Claudius Claudianus c.370-405 AD): Strength does not depend on blood, and one of Ovid's pieces of seduction advice from Ars Amatoria (Publius Ovidius Naso 43 BC-17/18 $\mathrm{AD})$ : Let the teeth be free from staining [lit. 'rust']'. There are also pineapples, scalers, a lancet, a goats-foot elevator and pelicans (the extraction instruments not the birds) as well as a couple of what look like rotten teeth. Pineapples were rare and expensive, and may be present for their reputed healing properties.

\section{SUMMARY}

This second paper in a series discussing the Hancocks criteria for a name to be successfully applied to the dental profession looks at the exposure of the public to the new title of dentist, and the crucial development and cultivation of the dental patient: 'they are ... essential to, our identity. Until we can agree that identity among ourselves we cannot expect others such as patients [and] public, ... to either understand our relationship to one another or indeed to respect our collective voice when we choose to, or need to, use it'.

Serious professional publications played their part, alongside less serious caricatures. At a time when publicity was not considered incompatible with professional dignity and ethics, newspaper advertisements, trades directories and trade cards spread the news of the existence of dentists, and dental patients as a group were addressed.

1. Hancocks S. What's in a name? Br Dent J 2005; 199: 65.

2. Bishop M. 'Dentists' and the establishment of the Anglo-American dental profession in the eighteenth century: part 1. The need for a name and an identity. Br Dent J 2014; 217: 537-540

3. Spilsbury F B. Every lady and gentleman their own dentist, as far as the operations will allow. Etc. London: Printed for the author, 1791.

4. Hunter J. Practical treatise on the Diseases of the 
Teeth etc. London: J. Johnson, 1778

5. Berdmore T. A treatise on the disorders and deformities of the teeth and gums. London: Printed for the author, 1768.

6. Griffiths R. The Monthly Review, or Literary Journal 1768: XXXIX: 95-100 and 157.

7. Review of new publications. The Gentleman's Magazine and Historical Chronicle for the year 1790; 60: 731 .

8. Wooffendale R. Practical observations on the human teeth. London: Printed for J. Johnson, and Messrs. Richardson and Urquhart, 1783.

9. De Chemant N D. A dissertation on artificial teeth in general etc. London: J. Barker, 1797.

10. Wooffendale R. Practical observations on the human teeth. London: Printed for J. Johnson, and Messrs. Richardson and Urquhart, 1783 103/4 e.g.

11. Hargreaves A S. White as whales bone dental services in early modern England. p 81. Leeds: Northern Universities Press, 1998.

12. Greenwood I. Advertisement in the Massachusetts Centinel (sic). 27 May 1789.

13. Nelson F. Letter to Lord Nelson 17 Dec 1794. British Library Manuscripts Nelson Papers Add. MS 34988 Vol LXVII ff 123-376.
14. Chesterfield to Stanhope. Letter LXVIII London, April 19,0 S. 1749

15. Chesterfield to Stanhope. Letter CXXIII London, November 12, 0 S. 1750.

16. Appréciations sur Pierre Fauchard. Illustration available at http://www.biusante.parisdescartes.fr/ fauchard/05-01.htm (accessed October 2014).

17. King R. The making of the Dentiste c.1650-1760. Aldershot: Ashgate, 1998

18. Jeze. État ou Tableau de la Ville de Paris. 1760 Premiere Partie; Choses Necessaires a la vie. Dentistes. Paris: Chez Prault pere et al., 1760. 5, 6.

19. Hargreaves A. Personal communication 25.10.2013. Daily Advertiser, Feb 18. 1751

20. Purland Collection at the Wellcome library. The Post Boy December 1719 PC 67.

21. The Works of Henry Fielding. Journal of a Voyage to Lisbon Vol X. pp 224-225. London: Bickers and Son, H Sotheran, 1871.

22. Menzies Campbell Collections at the Royal College of Surgeons of England. MSO286 item 5 Odontological advertisements, 1709-1850.

23. Purland Collection at the Wellcome library.

24. Morning Herald 27 January. York and Soho.

25. Bath Chronicle 6 May 1778.
26. Morning Chronicle 4 February 1780

27. Reading Mercury 19 March 1792.

28. Carington Bowles Spectators at a print shop. 25 June 1774. British Museum catalogue Vol III. II.

29. Undated, c.1760s. The publishing firm of Bowles and Carver of 69 St Paul's Church Yard was founded in 1763.

30. Copies in the Purland collection at the Wellcome Library, and the Menzies Campbell Collection RCS Edin. (McGowan D, Park M. The art of dentistry. Dental History Magazine 2012; 6: 2-6.)

31. Several images of Martin van Butchell are available at: http://wellcomeimages.org/. (Enter van Butchell in Search)

32. Carington Bowles. London. British Museum Catalogue Vol 66760.

33. BDA Museum collection

34. Banks S S. The Banks Collection of trade cards. British Museum K3.14. 54.19, 54.32, 54.23.

35. Trade card for Hemet and Scarman, dentists. British Museum Banks Collection; Reg. No. D, 2.738; PRN. PPA330921: Image available at http://www.britishmuseum.org/research/collection_online/collection_object details.aspx?objectld=3386923\&tpartld=1\&tsearchText= hemet+scarman\&tpage $=1$ (accessed October 2014). 